\title{
Effect Of The Use Of Cooperative Learning Approach Type Think Pair Share And Students Interest In Reading Towards Students Skill In Writing Observation Report Text
}

\author{
Rolli Gautama, Syahrul R, Abdurrahman \\ Universitas Negeri Padang \\ rolli gautama@yahoo.co.id
}

\begin{abstract}
This research aims to describe the effect of the use of cooperative learning approach type think pair share and interest of students in reading towards certain skill in writing observation report text in grade ten of senior high school. This research deploys a quantitative research using experiment method by applying static group comparison design. The sample of this research is grade ten students which are chosen by using purposive random technique. The finding suggests several things. First, there is impact in using cooperative learning approach type think pair share towards students' skill in writing observation report text. Second, there's also impact of the higher and the lower students' interest in reading toward students' skill in writing observation report text. Third, there's no relation between cooperative learning approach type think pair share and students' interest in reading toward students'skill in writing observation report text.
\end{abstract}

Keywords-effect; think pair share; reading interest; observation report

\section{INTRODUCTION}

The learning of bahasa Indonesia aims to to train students to be able to perform an effective and efficient communication based on common norms and rules applied in society, written or unwritten, stated by Abidin in Juliawati (2015, p.2). Furthermore, it is expected that the students can train their skills in writing. Writing skill is a skill of converting ideas into a written form by constructing whole, complete and clear sentences which can be understood by the readers.

However, writing seems to be an obstacle for number of students. It can be seen from Huy (2015, p.53) that students have problems in writing due to their lack of focus. Therefore, a better learning approach is needed. Cooperative learning approach type think pair share can be applied to fulfill this goal. Marhaeni in Nwaubani (2016, p. 4) finds there"s a significant impact of cooperative learning approach towards studentse confidence ( $F=754.104$ dan sig $=0,000 ; p<0,05)$ and also studentse skill in speaking $(F=60,325$ dan $\operatorname{sig}=0,000 ; p<0,05)$.

Writing skill is necessarily needed to be mastered by the students as it is demanded in Curriculum 2013. Thus, it provides some text genres; one of them is observation report text. Writing skill of Grade X sudents demanded in KI 4, KD 4.2. Nevertheless, the problems founded during the learning. As it is found by Juwani (2015, p.130) that grade X students of SMA N 3 Purbalingga had problems in writing this text. They only achieved scores below the level of 70.

Moreover, the researcher also found similar problems in SMA N 1 Payakumbuh. Based on the interview conducted on July 18, 2017, Ernageni as the teacher of bahasa Indonesia found out that the students face several problems in writing. First, they do not have a good skill in writing due to their lack of interest in reading. As the result, they do not comprehend the structure, language features and social function of observation report text. Second, students do not get well motivated in writing as well as they do not get enough exercises in writing. Third, the learning approach used by teachers is not attractive enough in engaging students ${ }^{\text {ee }}$ attention.

Cooperative learning approach type think pair share is expected to facilitatee the students during learning process. In addition, students can comprehend language features in observation report text easily. Also, students can do the exercise way easier since they do it in pair.

Students $^{\text {ee }}$ achievement in writing could also be influenced by their interest in reading. Ariani $(2015, \mathrm{p} .1)$ states that students ${ }^{e e}$ interest in reading give impacts to studentse skill in writing a story in grade X SMA N 4 Bandar Lampung. In addition, Wiyanti $\left(2014\right.$, p. 89) says students ${ }^{\text {ee }}$ interest in reading influences their speaking skill in SMA N of Jakarta. Also, Hardiyanti $\left(2014\right.$, p. 1) claims that students ${ }^{\text {ee }}$ interesting in reading give impacts to students ${ }^{\text {ee }}$ skill in writing speech in grade IX Middle School 2 Tambun Selatan. 
To sum up, the factors above lead the researcher to conduct a research on students ${ }^{\text {ee }}$ skill in writing observation report text entitled "Effect of the Use of Cooperative Learning Approach Type Think Pair Share and Students" Interest in Reading towards Students "e Skill in Writing Observation Report Text in Grade X at SMA N 1 Payakumbuh.

This research aims to several points. First, to describe the effect of the use of cooperative learning approach type think pair share towards studentse skill in writing observation report text in grade x at SMA N 1 Payakumbuh. Second, to describe the effect the effect of studentse interest in reading towards students skill in writing observation report text text in grade $\mathrm{x}$ at SMA N 1 Payakumbuh. Third, to describe the relation between cooperative learning approach type thik pair share, students ${ }^{\text {ee }}$ interest in reading and students skill in writing observation report text in grade $\mathrm{x}$ at SMA N 1 Payakumbuh.

\section{METHODS}

This research deployed a quantitative research since the data analysis done by analyzing numbers instead of words. Particular numbers in this research obtained from the questionnare of students ${ }^{\text {ee }}$ interest in reading and also the scores of students writing on observation report text. Meanwhile, the method applied in this research is experiment. Riduwan (2011, p. 50) says the experiment research is the experiment in which the researcher finds out the effect of particular variable towards other variable in a controlled condition. Ibnu (in Mayora 2003, p.195) states that experiment research is a research whose subject is given acts. Afterwards, they would be assessed on the effects of those acts.

This research used a quasi-experimental design. This research was going to find out the effect of particular acts towards variable in group experiment and controlled group. An experiment group consisted of a group of students who learn bahasa with cooperative learning approach type think pair share. Meanwhile, a controlled group consisted of a group of students who learn bahasa Indonesia with coventional approach.

The sample of this research was the entire students of grade ten SMA N 1 Payakumbuh registered in 2017/2018 academic year. The sample was obtained by using purposive sampling. The samples of classes were X Mipa 1 and X Mipa 2. Some factors make the researcher choose these classes. First, they had a quite similar scorees average. Second, they consisted of same number of students; there are 34 students in each class. Furthermore, there were two instruments used in this research, which were a questionnaire and a test. A questionnaire was used to figure out students ${ }^{\mathrm{ee}}$ interest in reading; meanwhile the test was used to figure out student's skill in writing.

The data analysis was divided into two steps of analysis, which are: 1.The Analysis of Questionnaire, which contains of following steps; First, Count all of the studentse scores. Second, put the scores in order (the highest to the lowest). Third, divide the students ${ }^{\text {ee }}$ interest in reading into two groups based on their scores; a high scorer group and a low scorer group, Arikunto (2018, p. 261). 2. The Analysis of Test. In order to analyze the test well, there were several things should be considered. First, adapt and adjust the scores based on PAP standard. Second, convert the scores of writing observation report text based on the scale of 10. Third, describe a the test's frequency. Fourth, display the data in a "histogram" form. Fifth, test the hypothesis. Sixth, analyze the data to achieve the conclusion.

\section{FINDING AND DISCUSSION}

The data findings will be discussed based on the theory which has been stated before. They were:

Students' Skill in Writing Observation Report Text Taught by Using Cooperative Learning Approach Type Think Pair Share and Conventional Approach

The findings of the first hypothesis testing suggests that there is effect in using the cooperative learning approach type think pair share towards students ${ }^{\text {ee }}$ skill in writing observation report text due to $\mathrm{F}_{\text {count }}(\mathrm{A})=109.55>$ $\mathrm{F}_{\text {table }}=4,17$ so that the Hypothesis $\left(\mathrm{H}_{0}\right)$ is rejected.

The students who were taught by cooperative learning approach type think pair share received higher scores compared to the students who were taught by using conventional approach. The average scores of students ${ }^{\text {ee }}$ skill in writing observation report text using cooperative learning approach type think pair share is 83.816, meanwhile the average scores of controlled group is 54.24 .

The test for students se skill in writing observation report text conducted in both class; experiment and controlled. There are no differences of the test. The test given to the students were the same. It was conducted to figure out the differences and the influences of these two learning approaches.

During the data collection, the researcher differentiated the students in a term of learning approach applied in their classroom. One class taught by using cooperative learning approach type think pair share, meanwhile other class taught by using conventional approach. During the process, a class taught by think pair share seemed to be more interested, engaged and motivated. On the other side, a class taught by using conventional approach seems to be less active and motivated. The students felt there's no breakthrough in their learning process.

The learning by using think pair share aims to ease and facilitate the students in writing session. According to Lie (2010, p. 28), cooperative learning approach gives opportunity to the students to work in pair or group, while the teacher acts as a facilitator. Therefore, because of this benefit, student can be more active and well-motivated during the learning process. 
Furthermore, cooperative learning approach type think pair share, gives the students " a responsibility task" during the process. Due to this situation, it can activate students critical thinking. Moreover, students can be well motivated during the learning process since they are demanded to be so. On the other hand, conventional method focuses on the teacher only. The teacher just shares information to the students without involving other interesting activities. As a result students cannot be well motivated, they just remain silent during the learning process, stated by Djafar (2001, p. 86). Besides, the teacher cannot evaluate students ,comprehension and assess their understanding as well.

\section{The Higher and The Lower Students' Interest in Reading Toward Students' Skill in Writing Observation Report Text}

The findings of the second hypothesis testing suggests that there students $^{\text {ee interest in reading toward students }}{ }^{\text {ee }}$ skill in writing observation report text, due to $F_{\text {count }}(B)=428,094>F_{\text {table }}$ $=4,17$ therefore the Hypothesis $\left(\mathrm{H}_{0}\right)$ is rejected.

Students with higher level of reading interest received higher scores as well, compared to students with lower level of reading interest. The finding shows that students with higher level of reading interest achieve the average score 92,573. Meanwhile, students with lower level of reading interest only reach the average score 64.816. Students with lower level of reading interest were grouped in experiment class taught by cooperative learning approach achieved the average score 78.394. On the other hand, students with lower level of reading were grouped in controlled class taught by conventional approach only reach the score 51,23 . In short, of the higher and the lower students ${ }^{\text {ee }}$ interest in reading toward students ${ }^{\text {ee }}$ skill in writing observation report text.

The Cooperative learning approach type think pair share gives some advantages. It can activate students passion in learning, it engange students to think critically and motivate the students to be well confident during the learning process. Besides, this is suitable for the students with the higher level of reading. According to Lie (2007. p. 57), the advantages by applying cooperative learning approach type think pair share are as follows. First, it can activate students participation. Every question and statement delivered by the teachers can persuade them to speak and take participation during the class. Second, this approach is suitable for a simple task. Third, students can involve in teamwork even more. Fourth, the classroom interaction can be way better and effective. Fifth, students can transform into group easily.

In addition, applying think pair share can facilitate the students with lower level of reading interest while writing observation report text. Slavin (2005, p. 92) states that cooperative learning can enhance students ${ }^{\text {ce }}$ cognitive and motivate them in reaching their goals in the learning process. Study in group can spare more time and effort in order to help each other, assessing each other progress and motivating each other as well. By this, students with lower level of reading interest can get pushed in improving their skill.

On the other side, conventional approach places the students as receiver only during the learning process. As a result, they become less-active in the classroom. They do not feel free to deliver their opinion and ideas. This statement is similar to one stated by Roestiyah $(2008$, p. 138). She says that the disadvantage of conventional approach is the teachers are not able to control and assess students ${ }^{\text {ee }}$ achievement in learning process.

\section{Relation Between Cooperative Learning Approach Type Think Pair Share and Students'Interest in Reading \\ Toward Students ${ }^{\text {ee }}$ Skill in Writing Observation Report Text}

The findings of the third hypothesis testing suggests that there s no relation between cooperative learning approach type think pair share and students ${ }^{e c}$ interest in reading toward students seskill in writing observation report text due to $F_{\text {count }}=0,005<\mathrm{F}_{\text {table }}=4,17$, thus $\mathrm{H}_{0}$ is accepted and $\mathrm{H}_{1}$ is rejected.

Reading interest is not always being a main factor influence students ${ }^{e e}$ achievement. There are many other factors such as passion intelligence. Besides, teachers ${ }^{\text {ee }}$ preparation in using this cooperative learning approach type think pair share will give influence toward student's achievement.

No-relation between these issues can also be seen from the average scores of students ${ }^{\text {ee }}$ writing skill. The scores of writing test in experiment class with the higher level and the lower level of reading interest students are higher compare to scores of the students in a controlled class.

\section{CONCLUSION}

Based on the research, there are several things can be concluded. First, there is impact in using cooperative learning approach type think pair share towards studentse ${ }^{\text {ee }}$ skill in writing observation report text, due to $F_{\text {count }}(A)=$ $109,55>\mathrm{F}_{\text {table }}=4,17$ so that the Hypothesis $\left(\mathrm{H}_{0}\right)$ is rejected. Second, there s also impact of the higher and the lower students $^{\text {ec interest in reading toward students }}{ }^{\text {ee }}$ skill in writing observation report text, due to $\mathrm{F}_{\text {count }}(\mathrm{B})=428,094>\mathrm{F}_{\text {table }}$ $=4,17$ therefore the Hypothesis $\left(\mathrm{H}_{0}\right)$ is rejected. Third, there"s no relation between cooperative learning approach type think pair share and students ${ }^{\text {ee }}$ interest in reading toward students skill in writing observation report text due to $\mathrm{F}_{\text {count }}=$ $0,005<\mathrm{F}_{\text {table }}=4,17$, thus $\mathrm{H}_{0}$ is accepted and $\mathrm{H}_{1}$ is rejected. 
There are several points suggested in this research. First, the teachers of bahasa Indonesia can apply cooperative learning approach type think pair share in order to get the students well motivated and interested as well. Second, it is suggested that the students of grade X SMA N 1 Payakumbuh to be passionate in writing, especially observation report text, since it can activate critical thinking and enhance understanding. Third, above all suggestions, the further critics, comments and suggestion are expected from the readers in order to improve this research and its further development in the future.

\section{References}

Ariani, S. R. (2015). Hubungan minat baca dan kemampuan menulis cerita pendek kelas x SMA N 4 Bandar Lampung. Jurnal Kata (Bahasa, Sastra, Dan Pembelajarannya) 3 (2), 1-10.

Arikunto, S. (2008). Dasar-dasar evaluasi pendidikan. Jakarta: Bumi Aksara.

Djafar, TZ. (2001). Kontribusi strategi pembelajaran terhadap hasil belajar. Padang: FIP UNP.

Hardiyanti. (2014). Pengaruh minat baca dan model pembelajaran terhadap kemampuan menulis teks pidato. Jurnal Kata (Bahasa, Sasatra, dan Pembelajarannya) 2 (3), 1-10.

Huy, N.T. (2015). Problems affecting learning writing skill of grade 11at thong linh SMA N. Asian Journal of Educational Research 3(2), 53-69.

Juliawati, N. K. (2015). Pembelajaran menulis teks laporan hasil observasi berbasis kearifan lokal pada siswa kelas VII A4 SMP Negeri 1 Singaraja. Journal Jurusan Pendidikan Bahasa dan Sastra Indonesia Undiksha 3(1), 1-10.

Juwani. (2015). Efektivitas metode group investigation dalam meningkatkan motivasi belajar dan kemampuan menulis teks laporan hasil observasi. Jurnal Metafora 2(1), 130-142.

Lie, A. (2007). Cooperative learning : mempraktikkan cooperative learning di ruang-ruang kelas. Jakarta: Gramedia Widiasarana.

Lie, A. (2010). Cooperative Learning. Jakarta: Grasindo.

Mayora. (2017). Pengaruh model discovery learning berbantuan media audiovisual terhadap keterampilan menulis teks anekdot siswa kelas x Sma Negeri 1 Lembah Gumanti Kabupaten Solok. Jurnal Pendidikan Bahasa dan Sastra Indonesia 6(2), 192-200.

Nwaubani, O.K. (2016). Effects of think-pair share (TPS) and student teams-achievement divisions (STAD) instructional strategies on senior secondary school studentse achievement in economics. Australian Journal of Basic and Applied Sciences 10(13), 1-9.

Riduwan. (2005). Belajar Mudah Penelitian Anak untuk Guru, Karyawan, dan Penelitian Pemula: Bandung: Alfabeta. Roestiyah. (2008). Strategi Belajar Mengajar. Jakarta: Rineka Cipta.

Slavin, R. E. (2005). Cooperative Learning. Bandung: Penerbit Nusa Media.

Wiyanti, E. (2014). Peran minat membaca dan penguasaan kosa kata terhadap keterampilan berbicara bahasa Indonesia. Jurnal Deiksis 6 (2), 89-100. 